\title{
COMPARATIVE STUDY ON SELF-ASSESSMENT OF TEACHING COMPETENCIES OF PE STUDENT TEACHERS FROM POLAND AND KOSOVO
}

\author{
Michał Bronikowski ${ }^{1}$, Ida Laudańska-Krzemińska ${ }^{1}$, Adam Kantanista ${ }^{1}$, \\ Malgorzata Bronikowska ${ }^{1}$, Ewa Szczepanowska ${ }^{2}$, Besnik Morina ${ }^{3}$ \\ University School of Physical Education ${ }^{1}$, Poznań, Poland \\ Szczecin University², Szczecin, Poland \\ University of Pristina ${ }^{3}$, Pristina, Kosovo
}

\begin{abstract}
Research backgrounds and hypothesis. This study investigates the student teachers' preparation for the practical school placement in Poland and Kosovo. Considering the two countries with different academic backgrounds there might be reasonable differences in the state of students' preparation to work practice. While other research concentrates on teachers' supervision during practical placement the literature review carried out for this paper illustrates that teaching practicum, which has been a focal point of many academic discussions, has been relatively little researched, especially from the students' perspective of the process. Understanding the differences regarding various academic systems may bring some more light into the search for the most effective ways of preparing student teachers for the school practical placement.

Research aim. The purpose of the study was to analyse the student teachers' assessments of their actual teaching competencies in order to further prepare a Cooperating PE Teachers Programme (COPET) at both universities. A sample of 154 second year Bachelor undergraduates in Poznań and 128 students from Pristina and respectively 109 from Master students from Poznań, and 45 from Master students of the international post-graduate programme in Physical Education and Sport in Kosovo were surveyed.

Research method. Quantitative data were collected via the Pre-Service PE Teachers Self-Assessment Questionnaire including 25-items concerning three areas: organizational, didactic and pedagogical. A multivariate analysis of variance showed the differences between students from Poznań and Pristina.

Research results. In our own research, the analysis of progression (visible in the difference between Bachelor and Master students) in their self-assessment indicates more critical self-reflection present in the assessments of students in Poznan. This was not common in the self-assessment of the students in Pristina as levels of their selfassessment at the two phases of the PETE programme (Bachelor and Master) were similar.

Discussion and conclusions. Recommendations for further improvements of PETE programmes in both Polish and Kosovan Higher Education Institutions concern the introduction of a COPET programme. Improving teaching practice and professional preparedness of student teachers requires elevating the quality of academic teaching delivered to students throughout their studies. This especially concerns subjects dealing with the teaching of practical and methodological skills. Equally important is the quality of early practical experience.
\end{abstract}

Keywords: PE practical school placement, student teachers' competencies, self-assessment.

\section{INTRODUCION}

$\mathrm{P}$ reparing highly qualified physical education teachers has become a critical issue for the legitimization of the subject and its future as part of school curricula alongside other, more academic, subjects. However, an even equipping student teacher with the most essential knowledge, skills, and dispositions (Darling-Hammond, 2001; Johnson, Reiman, 2007) does not appear to be sufficient. 
The literature review carried out for this paper illustrates that although teaching practicum has been a focal point of many academic discussions (Hascher et al., 2004; Behets, Vergauwen, 2006; Anderson, 2007; Ayesr, Housner, 2008), there is relatively little research on the student teachers' perspective of the process (Kelly, Tannehill, 2012). Other research has concentrated on teachers' supervision during practical placement widely studied (Shaughnessy, 2004; Tschennen-Moran, Hoy, 2007).

A decisive part of physical education teachers' programmes (PETE) comes through teaching practice, which shapes the beginnings of one's involvement in the teaching profession (Little, 1990; Hiebert et al., 2002; Dunning et al., 2011; Meegan et al., 2013). This is also a decisive moment in the development of teaching efficacy which is determined as much by external sources (supervisors, school climate and school personnel) as by successful or unsuccessful pedagogical experiences (Caires et al., 2012). Successful experiences are characterised by a correlation between mastery of content knowledge and learners' achievements, between the effective use of teaching skills (Leinhardt, Greeno, 1986), and control of pupils' behaviour, and between feedback received and the awareness and thinking processes that teachers experience in the situations of teaching (Graham, 2006; Zach et al., 2012). As such, teaching practice can be a difficult time when there is often an imbalance between what student teachers are taught about teaching and learning at university, and what they observe and how are expected to perform in a school environment.

Teaching practice provides student teachers with an opportunity to gain practical teaching experience by becoming immersed in a school environment. It is during such work experience that the realities of teaching are encountered and student teachers not only develop their pedagogical skills but also become socialized into the teaching profession (Hoy, Woolfolk, 1990; Guyton et al., 1991; Su, 1992; Larson, 2005).

Belton et al. (2010) investigated the impact of a new Cooperating PE Teachers Programme (COPET) from the cooperating teacher's perspective. They found that a more well-defined role allowed the teachers to provide student teachers with an enhanced learning environment during the work placement period. In the subsequent research (Dunning et al. 2011), a majority of student teachers were found to have reported feeling well prepared and more confident prior to, and during, teaching practice. COPET program is a novelty in PETE study programmes, which was developed at some universities when it became clear that in schools with non-COPET trained cooperating teachers, the experiences of practice were less successful for student teachers. D. Tannehill and D. Zakrajsek (1988) reported that non-trained cooperating teachers' feedback tended to fall outside of lesson assessment guidelines and areas which were of concern to the developing of student teacher's teaching skills. It is worth mentioning that COPET programme did not exist at none of the universities (Poznań and Pristina) examined in our research. Therefore our work can be related to an important discussion about teacher professionalization.

Introducing such COPET programmes requires recognition of the potential strong and weak points in the process of preparation towards work placement. The purpose of this study was to compare physical education student teachers' selfassessment of their levels of overall and specific teaching competencies concerning school practice at different levels of their teacher training in two different backgrounds of Poland and Kosovo. At the University School of Physical Education in Poznań (Poland) programme COPET is being prepared to be introduced and one of the reasons why the University of Pristina (Kosovo) has been chosen for this comparative study was the lack of such a programme and the relatively poor quality of practical school placements in case of PE student teachers. Indeed, this is one of the reasons that the Faculty of Physical Education at the University of Pristina was not granted accreditation recently (Project Inception Report, 2012). The EU has funded an International Masters programme at the University of Pristina as part of a wider European Union project (EuropeAid/130886/C/SER/ KOS) after the programme of physical education studies run by the University of Pristina failed the accreditation process in 2010 (Project Inception Report, 2012).

Poland became a democratic country after the fall of Communism in 1989 and adopted the Bologna system of Higher Education in 1999. In contrast, the case of Kosovan educational system is unique. Because of recent domestic conflict, most educational changes and adjustments have occurred only recently. Although education is a top priority for Kosovo, schools have to deal 
with insufficient financial, material and personnel resources. With limited sporting facilities (many of which were destroyed during the periods of the war) and the low quality of physical education teachers' education, the status of PE as a school subject seems vulnerable. For example in Poland almost $70 \%$ of schools have a sports hall (NIK, 2010). Furthermore, there have been 2012 additional football complexes built as a part of governmental initiative for the 2012 European Football Championships and 1400 indoor swimming pools will be ready by 2015 . The situation with infrastructure in Kosovo is far from satisfactory.

A key priority for the Kosovan Ministry of Education, Science and Technology (MEST, 2004, 2010 ) is improvement of access to higher education by increasing participation of the 18-25 years age group from 22 to $35 \%$ by the year 2015 (Project Inception Report, 2012), whereas in Poland it is already at around 50\% (Report OECD, 2010). There is also a problem with facilities of the Faculty of Sport Science in Pristina, which lacks not only sport gyms halls and swimming pools, but also basic apparatus and equipment. This can be compared to the University of Physical Education in Poznań which owns three full size sports hall, a gymnastics gym, swimming pool, field hockey stadium with artificial grass and a regulation 400 meter track for athletics around it. Furthermore, at the Faculty of Physical Education in Pristina both students and teaching staff lack relevant up-to-date publications or access to international databases and online journals whereas in Poznań students and academics have full access to a very well-equipped modern library providing numerous national and international journals and books.

\section{RESEARCH METHODS}

Participants. The study is related to student teachers of the Physical Education Faculty from University School of Physical Education in Poznań, Poland and similar faculty at the University of Pristina, Kosovo. Data was collected from student teachers of both genders at the respective faculties. The subjects, 154 second-year Bachelor undergraduates in Poznań and 128 student teachers from Pristina, completed the questionnaire. This was supplemented by 109 questionnaires from Masters Programme participants from Poznań, and 45 from student teachers of the international post-graduate programme (Master programme) in Physical Education in Kosovo. All data was anonymous and collected by a trained member of the faculty during one of the classes in the academic year of 2012/2013. The examined subjects were given relevant information on the purpose of the survey.

Research instrument. The idea of the design of the study was based on the research of T. Hascher et al. and P. Moser (2004), who examined student teachers and mentors on preparing, teaching and post-processing lessons after each work placement. Data for the study was collected with the use of the Pre-service PE Teacher Self-Assessment Questionnaire. The questionnaire was developed by M. Bronikowski and A. Kantanista (2013) to examine physical education student teachers' preparation for school practice. In the preparation of that research tool a mixed methodology (open issues, personal interviews with the experts, focus groups and discussions) was used. The panels of experts were approached -59 last year post-graduate student teachers of PETE course, 6 cooperating PE teachers with a minimum of 15 years of teaching experience and 5 university tutors supervising practical school placement were asked to verify the general areas and each of the items. The reliability of the questionnaire was checked on a group of Polish student teachers (test-retest reliability 0.91). The questionnaire was translated into Albanian and before handing it to the student teachers in Kosovo it was cross-checked for the accuracy of translation with several Physical Education experts, members of the Physical Education Faculty from Pristina. The questionnaire consists of 25-items divided into 3 sections reflecting the most essential areas of teachers' preparation, with a Likert scale of 1 (very poor) to 5 (very good) describing the level of selfassessment. These three areas concerned:

1. The organizational area of physical education processes included 7 items concerning the following aspects: diagnosing conditions for $\mathrm{PE}$ in school, planning daily teaching activities, teacher documentation, all-staff meetings and PE departmental team meetings, organization of school trips.

2. The didactic area of the physical education process included 12 items concerning the following aspects: diagnosis of pupils' interests, physical fitness and development, preparing lesson plans, observing other lessons, assisting in the organization of a PE lesson and organization of lessons by oneself, fulfilling national PE curricula standards, teaching 6-9 years old pupils, 
organizing sport and dancing lessons, evaluating pupils' efforts, and analysing the effectiveness of own teaching (self-evaluation, critical reflection)

3. The pedagogical area of the physical education process included 6 items concerning the following aspects: diagnosis of pupils' behavioural problems, collaborating with teachers of other subjects and with the school pedagogue and school psychologist in solving problems appearing in a class, dealing with conflict situations (aggression, emotional problems), communicating with pupil's parents during school meetings, and providing first aid to pupils in case of emergency.

Statistical analysis. Average scores were calculated for each of the three areas to provide an overall view and for every single of the 25 items to obtain more specific information. Differences between the groups were tested with Friedman's ANOVA and a Wilcoxon signed-rank test. The Mann-Whitney $U$ test was employed to determine the significance of differences between groups in each of the 25 items. The level of significance was set at $p<0.05$. Statistical calculations were performed by using the Statistica 10 software package (StatSoft Inc., Tulsa, OK).

\section{RESEARCH RESULTS}

The data in Table 1 presents the mean scores obtained in organizational, didactic and pedagogical areas by PE student teachers from Poland and Kosovo.

Undergraduate Polish student teachers declared the highest preparation for realization of didactic tasks followed by realization of duties concerning pedagogical and organizational aspects. In the opinion of undergraduate Kosovan students they were best prepared for working in pedagogical, followed by didactic and finally organizational areas. There were significant $(\mathrm{p} \leq 0.001)$ differences between the mean scores among Polish and Kosovan students. Students from Kosovo declared a generally higher preparation in all areas compared to declarations of Polish students ( $\mathrm{p} \leq 0.001)$.

Polish Master Degree student teachers declared the highest level of preparation for realization of didactic tasks, followed by pedagogical and finally organizational aspects and these differences were significant ( $p \leq 0.001)$. In the opinion of Kosovan Master Degree student teachers, they assessed the best preparation for working in didactic areas,

Table 1. Mean scores and standard deviations of Physical Education students from Poland and Kosovo in organizational, didactic and pedagogical areas

\begin{tabular}{|c|c|c|c|c|c|}
\hline Academic year & $\begin{array}{c}\text { Organizational } \\
\text { Area } \\
\text { Mean/SD } \\
\end{array}$ & $\begin{array}{c}\text { Didactic } \\
\text { Area Mean/SD }\end{array}$ & $\begin{array}{c}\text { Pedagogical } \\
\text { Area } \\
\text { Mean/SD }\end{array}$ & $\begin{array}{c}\text { Friedman's test } \\
\left(c^{2}\right) \\
\text { p value }\end{array}$ & $\begin{array}{l}\text { Wilcoxon signed- } \\
\text { rank test }\end{array}$ \\
\hline \multicolumn{6}{|c|}{ Bachelor Degree level } \\
\hline $\begin{array}{l}\text { Poland } \\
(\mathrm{n}=154)\end{array}$ & $\begin{array}{l}3.02 \\
0.58\end{array}$ & $\begin{array}{l}3.37 \\
0.57\end{array}$ & $\begin{array}{l}3.18 \\
0.64\end{array}$ & 0.000 & $\mathrm{a}^{* * *}, \mathrm{~b}^{* * *}, \mathrm{c}^{* * *}$ \\
\hline $\begin{array}{l}\text { Kosovo } \\
(\mathrm{n}=128)\end{array}$ & $\begin{array}{l}3.73 \\
0.46\end{array}$ & $\begin{array}{l}3.90 \\
0.49\end{array}$ & $\begin{array}{l}4.04 \\
0.54\end{array}$ & 0.000 & $a^{* * *}, b^{* * *}, c^{* * *}$ \\
\hline $\begin{array}{l}\text { Test U Mann-Whitney; } \\
\text { p value }\end{array}$ & 0.000 & 0.000 & 0.000 & & \\
\hline \multicolumn{6}{|c|}{ Master Degree level } \\
\hline $\begin{array}{l}\text { Poland } \\
(\mathrm{n}=109)\end{array}$ & $\begin{array}{l}3.51 \\
0.68\end{array}$ & $\begin{array}{l}4.08 \\
0.49\end{array}$ & $\begin{array}{l}3.72 \\
0.68\end{array}$ & 0.000 & $a^{* * *}, b^{* * *}, c^{* * *}$ \\
\hline $\begin{array}{l}\text { Kosovo } \\
(\mathrm{n}=45)\end{array}$ & $\begin{array}{l}3.67 \\
1.02\end{array}$ & $\begin{array}{l}4.18 \\
0.48\end{array}$ & $\begin{array}{l}4.00 \\
0.70\end{array}$ & 0.004 & $a^{* * *}, b^{*}$ \\
\hline $\begin{array}{l}\text { Test U Mann-Whitney; } \\
\text { p value }\end{array}$ & 0.151 & 0.412 & 0.019 & & \\
\hline \multicolumn{6}{|c|}{ Bachelor vs. Master Degree Poland } \\
\hline $\begin{array}{l}\text { Test U Mann-Whitney; } \\
\text { p value }\end{array}$ & 0.000 & 0.000 & 0.000 & & \\
\hline \multicolumn{6}{|c|}{ Bachelor vs. Master Degree Kosovo } \\
\hline $\begin{array}{c}\text { Test U Mann-Whitney; } \\
\text { p value }\end{array}$ & 0.675 & 0.001 & 0.813 & & \\
\hline
\end{tabular}

Note. $*-p \leq 0.05 ; * *-p \leq 0.01 ; * * *-p \leq 0.001$. a - significant difference between mean scores achieved in organizational and didactic areas. $\mathrm{b}$ - significant difference between mean scores achieved in organizational and pedagogical areas. $\mathrm{c}-$ significant difference between mean scores achieved in didactic and pedagogical areas. 
which was statistically higher than preparation for organizational tasks $(\mathrm{p} \leq 0.001)$. The statistical analysis indicated that students from Kosovo declared a higher preparation in the pedagogical area when compared to responses of Polish students $(\mathrm{p} \leq 0.05)$.

There were no differences in self-assessment between Bachelor and Master Degree Kosovan student teachers in organizational and pedagogical areas. This can be contrasted to Polish students, where differences were observed in all areas (Table 1).

Bachelor and Master student teachers' responses to all the questions included in organizational, didactic and pedagogical areas are presented in Table 2.

Bachelor Kosovan student teachers assessed their preparation in organizational areas at a higher

Table 2. Mean scores of Physical Education students from Poland and Kosovo in specific aspects of their preparation for teaching practice

\begin{tabular}{|c|c|c|c|c|c|c|}
\hline \multirow{2}{*}{ Student teacher is prepared to: } & \multicolumn{3}{|c|}{ Bachelor Degree } & \multicolumn{3}{|c|}{ Master Degree } \\
\hline & PL & KOS & p value & PL & KOS & p value \\
\hline \multicolumn{7}{|l|}{ In organizational aspects: } \\
\hline 1. Diagnose conditions for PE in school & 2.91 & 1.78 & 0.000 & 3.60 & 3.88 & 0.074 \\
\hline $\begin{array}{l}\text { 2. Analyze PE teacher's teaching documentation (program, } \\
\text { trading system) }\end{array}$ & 2.73 & 3.86 & 0.000 & 3.44 & 3.86 & 0.009 \\
\hline $\begin{array}{l}\text { 3. Participate in teaching staff meetings (raising questions, } \\
\text { referring topics related to physical education) }\end{array}$ & 2.91 & 4.35 & 0.000 & 3.22 & 4.31 & 0.000 \\
\hline $\begin{array}{l}\text { 4. Participate in PE teachers' meetings concerning professional } \\
\text { development }\end{array}$ & 2.93 & 4.06 & 0.000 & 3.11 & 4.28 & 0.000 \\
\hline 5. Plan a calendar (schedule) of sport events over the school year & 3.49 & 3.92 & 0.000 & 3.77 & 4.06 & 0.070 \\
\hline $\begin{array}{l}\text { 6. Organize school trips to interschool competitions (preparation } \\
\text { of appropriate documentations) }\end{array}$ & 3.21 & 4.17 & 0.000 & 3.66 & 3.91 & 0.154 \\
\hline 7. Plan activities for each day of the practice period in school & 2.99 & 3.95 & 0.000 & 3.96 & 3.80 & 0.962 \\
\hline \multicolumn{7}{|l|}{ In didactic aspects: } \\
\hline 1. Diagnose pupils' interests & 3.54 & 3.87 & 0.013 & 4.01 & 4.15 & 0.314 \\
\hline 2. Diagnose pupils' physical fitness and physical development & 3.61 & 4.08 & 0.000 & 4.20 & 4.31 & 0.329 \\
\hline $\begin{array}{l}\text { 3. Plan PE lesson (prepare a lesson plan with objectives, } \\
\text { learning outcomes) }\end{array}$ & 3.54 & 3.99 & 0.000 & 4.61 & 3.82 & 0.000 \\
\hline $\begin{array}{l}\text { 4. Observe lesson of PE teacher with analysing the aims, } \\
\text { learning contents and learning outcomes }\end{array}$ & 3.32 & 3.71 & 0.000 & 4.32 & 3.88 & 0.002 \\
\hline 5. Assist PE teacher in organizing a PE lesson & 3.83 & 3.65 & 0.037 & 4.59 & 4.28 & 0.008 \\
\hline 6. Organize the PE lesson on their own & 3.25 & 4.06 & 0.000 & 4.38 & 4.37 & 0.733 \\
\hline 7. Fulfill national curricula in PE lessons & 3.16 & 3.78 & 0000 & 3.86 & 3.42 & 0.043 \\
\hline 8. Organize PE classes for 6 to 9 year olds & 3.21 & 3.39 & 0.101 & 4.04 & 3.93 & 0.792 \\
\hline 9. Organize sport lessons & 3.73 & 4.24 & 0.000 & 4.48 & 4.28 & 0.393 \\
\hline 10. Organize dancing classes in school PE & 2.45 & 4.35 & 0.000 & 2.83 & 3.60 & 0.001 \\
\hline 11. Evaluate pupil's work (give grades) & 3.43 & 3.58 & 0.125 & 3.84 & 4.33 & 0.000 \\
\hline $\begin{array}{l}\text { 12. Analyze effectiveness of own teaching process (self- } \\
\text { evaluation, critical reflection) }\end{array}$ & 3.36 & 4.13 & 0.000 & 3.96 & 3.88 & 0.595 \\
\hline \multicolumn{7}{|l|}{ In pedagogical aspects: } \\
\hline 1. Diagnose pupils' personal problems & 3.05 & 4.14 & 0.000 & 3.70 & 4.22 & 0.000 \\
\hline $\begin{array}{l}\text { 2. Collaborate with teachers of other subjects in solving } \\
\text { problem situations appearing in the class }\end{array}$ & 3.31 & 4.15 & 0.000 & 3.91 & 4.33 & 0.009 \\
\hline $\begin{array}{l}\text { 3. Cooperate with school pedagogue and psychologist } \\
\text { (analysing situation of individual pupils) }\end{array}$ & 3.23 & 4.14 & 0.000 & 3.94 & 4.20 & 0.066 \\
\hline $\begin{array}{l}\text { 4. Deal with conflict situations, aggression, vandalism and other } \\
\text { behavioural and emotional problems }\end{array}$ & 3.00 & 4.02 & 0.000 & 3.62 & 4.24 & 0.000 \\
\hline $\begin{array}{l}\text { 5. Cooperate with pupil and his/her parents during parents' } \\
\text { meetings at school (giving information about a pupil) }\end{array}$ & 3.21 & 3.75 & 0.000 & 3.49 & 4.57 & 0.000 \\
\hline 6. Provide first medical aid to pupils suffering during PE & 3.29 & 4.02 & 0.000 & 3.69 & 4.26 & 0.000 \\
\hline
\end{tabular}


level when compared to Polish students ( $\mathrm{p} \leq 0.001)$. However, the particular skills to diagnose conditions for PE in school were rated higher by Polish students $(\mathrm{p} \leq 0.001)$. Preparedness for participating in teaching staff meetings, organizing school trips for interschool competitions (in the case of Kosovan students) or planning a calendar of sport events over the school year and organizing school trips for interschool competitions (in case of Polish students) were evaluated quite highly. In contrast, Kosovan students rated their skills in diagnosing conditions for PE in school, and Polish students in analysing PE teacher's teaching documentation, at low levels.

In most aspects of the didactic area, Bachelor Kosovan student teachers declared better preparation for the realization of different tasks when compared to their Polish peers. Only the ability to assist PE teachers in organizing a PE lesson was higher evaluated by Polish student teachers $(\mathrm{p} \leq 0.05)$. There were no significant differences between the Polish and Kosovan students in the declared level of preparation for organizing PE classes for 6 to 9 year olds and evaluating pupil's work (give grades). Mean scores of the specific aspects suggest that in the students' opinion they felt best prepared for organizing sports lessons (Polish and Kosovan students), organizing dancing classes in school PE (Kosovan students) and assisting PE teachers in organizing a PE class (Polish students).

Bachelor Kosovan student teachers rated their preparation in all specific aspects of the pedagogical area at a higher level than their Polish counterparts $(\mathrm{p} \leq 0.001)$. Mean scores suggest that specific aspects in the pedagogical area (when compared to organizational and didactic areas) were rated higher by Kosovan students. Polish students rated their preparation significantly lower, especially in such aspects as: dealing with conflict situations, aggression, vandalism and other behavioural and emotional problems and diagnosing pupils' personal problems (Table 2).

Kosovan Masters student teachers (Table 2) rated their preparation in organizational area higher when compared to Polish students in some specific aspects: analysing PE teacher's teaching documentation $(\mathrm{p} \leq 0.01)$, participating in teaching staff meetings ( $\mathrm{p} \leq 0.001)$, and PE teachers meetings concerning professional development $(\mathrm{p} \leq 0.001)$. Preparedness for participating in teaching staff meeting and participating in PE teachers meetings concerning professional development (in case of Kosovan students) or planning a calendar (schedule) of sport events over the school year (in case of Polish students) were all evaluated highly. In contrast, Kosovan students rated their skills of planning activities for each day of the practice period in school at a relatively low level. Likewise, Polish students evaluated participating in PE teachers meetings concerning professional development at a low level.

In the didactic area, Polish Masters student teachers rated their preparedness higher than Kosovan student teachers in four specific aspects: Planning a PE lesson $(\mathrm{p} \leq 0.001)$, observing lessons of another PE teacher with the analysis of the aims, learning contents and learning outcomes $(\mathrm{p} \leq 0.01)$, fulfilling national curricula in PE lessons $(\mathrm{p} \leq 0.05)$, and assisting a PE teacher in organizing a PE lesson $(\mathrm{p} \leq 0.01)$. However, students' preparedness to organize dancing classes in school $P E$ and evaluate pupil's work (giving grades) was rated better by Kosovan students $(\mathrm{p} \leq 0.001)$. Neither group of Master Degree student teacher felt very well-prepared for organizing dancing classes in school PE. Additionally, Kosovan Masters student teachers rated their preparation towards fulfilment of national curriculum in PE relatively low.

In comparison to Polish peers, Kosovan Masters student teachers rated their preparation in all specific aspects of pedagogical area at a significantly higher level. Mean scores suggest that specific aspects of the pedagogical area (when compared to organizational and didactic areas) are rated by Kosovan students higher. Conversely Polish students rated their preparation significantly lower, especially in such aspects as cooperating with a pupil and his/her parents during parents' meetings at school (giving information about a pupil).

\section{DISCUSSION}

Physical education student teachers at the University of Pristina clearly assessed their preparedness for carrying out tasks during practical school placement better than their counterparts from the University School of Physical Education in Poznań. Particularly clear differences were noted at the undergraduate Bachelor level. S. Zach et al. (2012) indicate that the high evaluation of one's self-efficacy during the early years of studying may be an outcome of 
student teachers' earlier perceptions about their abilities which led to them choosing this course of study in the first place. In their research the authors found a significant increase in teaching efficacy among pre-service teachers over the three years of a teacher preparation programme. S. Zach et al. (2012), as well as R. Gurvitch and M. W. Metzler (2009), found that the longer the pre-service teachers practice experience, the greater their efficacy. Findings of A. W. Hoy and R. B. Spero (2005) also allow for a cautious assumption that such an increase may continue in the same participants (student teachers) from the beginning of the programme through to graduation.

Generally, in our study, the student teachers' self-assessment of their preparation towards school work placements competencies in didactic area was evaluated higher than in the other two areas. The analysis of progression (visible in the difference between Bachelor and Master student teachers) in their self-assessment indicates more critical selfreflection (Gay, Kirkland, 2003) present in the assessments of students in Poznań. It is not common in the self-assessment of the students in Pristina, as levels of their self-assessment at the two phases of the PETE programme (Bachelor and Master) were similar. Critical self-reflection is a very important component of students' competencies and teaching skills (Patterson et al., 2002), but it is difficult to teach. Apparently, lack of self-critical approach was one of the reasons the faculty of Physical Education at University of Pristina has recently not been granted accreditation (Project Inception Report, 2012). The EU also noticed the need to ensure equal opportunities and standards in this respect, hence the financing of project with the aim of improving preparation of teaching staff and the level of training of PE teachers.

It is also worth mentioning the primary differences in social and academic contexts between the two universities. Student teachers in Kosovo do not have the chance to compare their level of teaching competencies against the skills and competencies of student peers abroad. Whereas students of the university in Poznan have a completely different experience in this respect as the number of students travelling abroad as part of the ERASMUS, or other programmes, is almost 150 every year. Also, a difference in the quality of academic staff international experience (participation in international conferences and projects) could be noted between the two universities. There are also more professors and academic staff with a $\mathrm{PhD}$ at the Faculty of Physical Education at University in Poznan than in Pristina (threefold). Obviously, holding a PhD degree or a number of full professorships positions are not direct indicators of a better teaching quality, but in a way describe a level of academic development and experience of the whole faculty.

Differences are also apparent in the access and use of scientific databases. The library of the University in Poznań provides free access to all databases significant for physical education and their use is growing each year not only among the staff, but also among the student teachers. Polish student teachers can also access many websites in their native language, which include teaching and training materials and examples of good educational practices. Quite few projects and websites are run with the substantive supervision of the Ministry of Education and refer directly to the Physical Education Core Curriculum. This type of technical support and background is not in place in Kosovo yet, thus it should not be expected that student teachers in Pristina would have a similar point of reference in self-assessment of their teaching abilities and preparation towards work placement as student teachers in Poznań. As a result there is a high relativity to the selfassessment of student teachers in Kosovo in relation to their teaching abilities, due to isolation from comparisons and assessments functioning in the EU, which may lead to apparently heightened self-assessment. Patterns of their school practice and academic educational standards remain in contrast to the standards expected by institutions and academic accreditation agencies in Europe. Although, the abovementioned information can't be used as an explanation of the findings of our study per se, however, they highlight some of the existing differences.

Our observations of the university teaching practice carried out during the stay at University of Pristina also indicate that the training of physical education teachers is dominated by emulation a system which teaches by imitating. A set of PE lesson work plans for school practice, prepared by the academic teachers of University of Pristina, is learned by heart, and later carried out by student teachers as part of their teaching routine during the practical placement in schools. Conversely, a 
more individual approach in $\mathrm{PE}$ teaching prevails in Poland. In the last decade Polish teachers had to re-direct their thinking about teacher-student relations. A typically instrumental, authoritarian, teacher-centred relation ought to be altered into a subjective, student-centred, partner-like relationship (Gardiner, Robinson, 2009).

It is also understandable that the situations described above, as well as different cultural and social backgrounds, and in fact different moments in the social and historical development of the two nations, may have affected the quality of education in both examined universities. But the outcomes of the study could serve as a valuable reference point in further development and $\mathrm{PE}$ teacher professionalization.

\section{CONSLUSIONS AND PERSPECTIVES}

The study was developed to explore PE student teachers' perspectives during teaching practice and find the potential differences in self-assessment in their professional preparation. The problems of self-assessment are quite evident. It would be helpful to have an external frame for evaluating the competencies, e. g. observation data, assessments by the cooperating teachers. To correlate selfassessment with action in practice could also be an important step to enhance this kind of study in the future. A study based on action research on the same cohort of student teachers could show its impact on didactic effectiveness to ensure equal learning opportunities for students with adequate feedback and sufficient support during school teaching practice.

Recommendations for further improvements of PETE programmes in both Polish and Kosovan Higher Education Institutions concern the introduction of a COPET programme. Improving teaching practice and professional preparedness of student teachers requires elevating the quality of academic teaching delivered to students throughout their studies. This especially concerns subjects dealing with the teaching of practical and methodological skills. Equally important is the quality of early practical experience. For the best effectiveness of teaching experience, the triad of firstly student teacher, secondly cooperating teachersin schools and thirdly university supervisors during practice, needs to coordinate their work in providing the best professional experience for the students. Therefore programmes like COPET, designed to support the abovementioned triad, seem to be a necessity. Recently, such guidelines have been developed to outline the role of the student teachers, PE teachers and university supervision at the Faculty of Physical Education in Poznan, with daily observation sheets to set and evaluate goals and lesson outcomes. Similar solution should take place in case of the Faculty of Physical Education in Pristina.

\section{REFERENCES}

Anderson, D. (2007). The role of cooperating teachers' power in student teaching. Education, 128 (2), 307-323.

Ayers, S., Housner, L. (2008). A descriptive analysis of undergraduate PETE programmes. Journal of Teaching in Physical Education, 27, 51-67.

Behets, D., Vergauwen, L. (2006). Learning to teach in the field. In D. Kirk et al. (Eds.). Handbook of Physical Education. London: Sage. P. 407-425.

Belton, S., Woods, C., Dunning, C., Meegan, S. (2010). The evaluation of a cooperating physical education teachers programme (COPET). European Physical Education Review 16, (2), 141-154.

Bronikowski, M., Kantanista. A. (2013). Students's selfevaluated level of practical preparation for teaching physical education. Rozprawy Naukowe AWF Wrocław, 3 (in print).

Caires, S., Almeida, L., Vieira, D. (2012). Becoming a teacher: Student teachers' experiences and perceptions about teaching practice. European Journal of Teacher Education, 35 (2), 163-178.

Darling-Hammond, L. (2001). Standard setting in teaching: Changes in licensing, certification, and assessment. In V. Richardson (Ed.), Handbook on Research on Teaching. Washington, D. C: American Educational Research Association. P. 751-776.

Dunning, C., Meegan, S., Woods, C., Belton, S. J. (2011). The impact of the COPET programme on the student PE teachers' teaching practice experiences. European Physical Education Review, 17 (2), 153-165.

Gardiner, W., Robinson, K. S. (2009). Paired field placements: A means for collaboration. The New Educator, 5 (1), 81-94.

Gay, G., Kirkland, K. (2003). Developing cultural critical consciousness and self-reflection in pre-service teacher education. Theory into Practice, 42 (3), 181-187. 
Graham, B. (2006). Conditions for successful field experiences: Perception of cooperating teachers. Teaching and Teacher Education, 22, 1118-1129.

Gurvitch, R., Metzler, M. W. (2009). The effects of laboratory-based and field-based practicum experience on pre-service teachers' self-efficacy. Teaching and Teacher Education, 25 (3), 437-443.

Guyton, E., Fox, M. C., Sisket, K. A. (1991). Comparison of teaching attitudes, teacher efficacy, and teacher performance of first year teachers prepared by alternative and traditional teacher education programs. Action in Teacher Education, 13 (2), 1-9.

Hascher, T., Cocord, Y., Moser, P. (2004). Forget about theory-practice is all? Student teachers' learning in practicum. Teachers and Teaching: Theory and Practice, 10 (6), 623-637.

Hiebert, J., Barkley, R. J., Gallimore, R., Stigler, J. W. (2002). A knowledge base for the teaching profession: What would it look like and how can we get one? Educational Researcher, 31, 3-15.

Hoy, A. W., Spero, R. B. (2005). Changes in teacher efficacy during the early years of teaching: A comparison of four measures. Teaching and Teacher Education, 21 (4), 343-356.

Hoy, W. K., Woolfolk, A. E. (1990). Socialization of student teachers. American Educational Research Journal, 27 (2), 279-300.

Johnson, L. E., Reiman, A. J. (2007). Beginning teacher disposition: Examining the moral/ethical domain. Journal of Teaching and Teacher Education, 23 (5), 676-687.

Kelly, S., Tannehill, D. (2012). The mentoring experiences of an Irish student teacher on his physical education teaching practice. Graduate Journal of Sport, Exercise \& Physical Education Research, 1, 47-64.

Larson, A. (2005). Pre-service teachers' field experience surprise. Some things never change. Physical Educator, 62 (3), 154-163.

Leinhardt, G., Greeno, J. G. (1986). The cognitive skill of teaching. Journal of Educational Psychology, 78 (2), $75-95$.

Little, J. W. (1990). The mentor phenomenon and the social organization of teaching. Review of Research in Education, 16, 297-351.
Meegan, S., Dunning, C., Belton, S.,Woods, C. (2013). Teaching practice: University supervisors' experiences and perceptions of a cooperating physical education teacher education programme. European Physical Education Review, 2, 1-16.

MEST. (2010). Curriculum Framework for Pre-School, Primary and Post-Secondary Education. Pristina: Ministry of Education Science and Technology.

MEST. (2004). Strategy for Development of Higher Education in Kosovo (2005-2015). Pristina: Ministry of Education Science and Technology.

NIK. (2010). Raport w sprawie kontroli "Wychowanie fizyczne i sport $w$ szkołach publicznych”. [Evaluation Report - Physical Education and Sport in Schools]. Warszawa: Najwyższa Izba Kontroli, Departament Nauki, Oświaty i Dziedzictwa Narodowego.

Patterson, C., Crooks, D., Lunyk-Child, O. (2002). A new perspective on competencies for self-directed learning. Journal of Nursing Education, 41 (1), 25-31.

Project Inception Report. (2012). Instrument for Preaccession, (IPA) Kosovo (UNSCR 1244): Centralised Programme 2009.

Report OECD. (2010). [6 06 2013]. Internet link: http:// www.uis.unesco.org/Education/Documents/oecd-eag2012-en.pdf

Shaughnessy, M. F. (2004). An interview with Anita Woolfolk: The educational psychology of teacher efficacy. Educational Psychology Review, 16, 153-176.

Su, J. Z. X. (1992). Sources of influence in pre-service teacher socialization. Journal of Education for Teaching: International research and pedagogy, 18 (3), 239-258.

Tannehill, D., Zakrajsek, D. (1988). What's happening in supervision of student teachers in secondary physical education? Journal of Teaching in Physical Education, 8 (1), 1-12.

Tschannen-Moran, M., Hoy, A. (2007). The differential antecedents of self-efficacy beliefs of novice and experienced teachers. Teaching and Teacher Education, 23, 944-956.

Zach, S., Harari I., Harari, N. (2012). Changes in teaching efficacy of pre-service teachers in physical education. Physical Education and Sport Pedagogy, 17 (5), 447-462. 


\title{
LENKIJOS IR KOSOVO KŪNO KULTŪROS MOKYTOJŲ PRAKTIKANTŲ MOKYMO KOMPETENCIJŲ ISIVERTINIMO LYGINAMASIS TYRIMAS
}

\author{
Michał Bronikowski ${ }^{1}$, Ida Laudańska-Krzemińska ${ }^{1}$, Adam Kantanista ${ }^{1}$, \\ Malgorzata Bronikowska ${ }^{1}$, Ewa Szczepanowska ${ }^{2}$, Besnik Morina ${ }^{3}$ \\ Kūno kultūros universitetinè mokykla', Poznane, Lenkija \\ Ščecino universitetas ${ }^{2}, \check{S}_{\text {čecinas, Lenkija }}$ \\ Prištinos universitetas ${ }^{3}$, Priština, Kosovas
}

\begin{abstract}
SANTRAUKA
Tyrimo pagrindimas ir hipotezė. Šiuo tyrimu analizuojamas studentų būsimų mokytojų parengimas pedagoginei praktikai mokykloje Lenkijoje ir Kosove. Kadangi šios šalys turi skirtingą akademinę sistemą, verta patyrinèti studentų parengimo praktiniam darbui būklę. Kitais tyrimais labiau akcentuojamas dėstytojų vadovavimas praktikai. Mokslinės literatūros analizė, atlikta šio tyrimo metu, rodo, kad mokytojavimo praktika iš tiesų yra mažai tyrinejjama, ypač studentu praktikantų. Supratus akademiniu sistemų skirtumus galima būtų veiksmingiau rengti studentus pedagoginei praktikai mokykloje.

Tikslas - išanalizuoti, kaip studentai vertina turimas pedagoginio darbo kompetencijas, ir parengti abieju universitetų Kūno kultūros mokytoju bendradarbiavimo programa. Tiriamieji: pirmos pakopos studentai - 154 iš Poznanès ir 128 iš Prištinos universitetų; antros pakopos studentai - 109 iš Poznanès ir 45 iš Tarptautinès kūno kultūros ir sporto magistrantūros programos iš Kosovo.

Metodai. Kiekybiniai duomenys surinkti naudojant Küno kultūros studentu praktikantu isivertinimo anketa, kurią sudare 25 klausimai iš trijų sričiu (organizavimo, didaktinès ir pedagoginès). Daugiamatè dispersinè analizė atskleide skirtumus tarp studentų iš Poznanès ir Prištinos.

Rezultatai. Isivertinimo progresinè analizè parodè, kad studentai iš Poznanès vertina save kritiškiau. Tai nebūdinga Prištinos universiteto studentams, kadangi abiejų pakopu (bakalauro ir magistro) studentų vertinimai buvo panašūs.

Aptarimas ir išvados. Rekomendacijos, kaip pagerinti kūno kultūros mokytojų pedagoginės praktikos programas tiek Lenkijos, tiek Kosovo aukštojo mokslo sistemoje, bus pateiktos Küno kultūros mokytoju bendradarbiavimo programoje. Pedagoginès praktikos ir mokytojo profesinio parengtumo gerinimas reikalauja tobulinti studiju kokybę visais studijų metais. Tai ypač aktualu praktinių ir metodologinių igūdžiu formavimo moduliu programoms. Pedagoginès praktikos kokybè taip pat labai svarbi.
\end{abstract}

Raktažodžiai: kūno kultūros pedagoginè praktika mokykloje, studentų būsimų mokytojų kompetencijos, isivertinimas.

Gauta 2013 m. rugpjūčio 29 d.

Received on 29 August, 2013 